\title{
Serotonergic regulation of energy metabolism in peripheral tissues
}

\author{
Wonsuk Choi*, Joon Ho Moon* and Hail Kim \\ Graduate School of Medical Science and Engineering, KAIST, Daejeon, Republic of Korea
}

Correspondence should be addressed to H Kim: hailkim@kaist.edu

*(W Choi and J H Moon contributed equally to this work)

\begin{abstract}
Serotonin is a biogenic amine synthesized from the essential amino acid tryptophan. Because serotonin cannot cross the blood-brain barrier, it functions differently in neuronal and non-neuronal tissues. In the CNS, serotonin regulates mood, behavior, appetite, and energy expenditure. Although most serotonin in the body is synthesized at the periphery, its biological roles have not been well elucidated. Older studies using chemical agonists and antagonists yielded conflicting results, because the complexity of serotonin receptors and the low selectivity of agonists and antagonists were not known. Several recent studies using specific knock-out of serotonin receptors have been performed to assess the role of peripheral serotonin in regulating energy metabolism. This review discusses (1) the tissue-specific roles of peripheral serotonin in regulating energy metabolism, (2) the mechanism by which dysfunctional peripheral serotonin signaling can progress to metabolic diseases, and (3) how peripheral serotonin signaling could be a therapeutic target for metabolic diseases.
\end{abstract}
Key Words
- peripheral serotonin
- energy metabolism
- pancreatic $\beta$-cells
- adipose tissue
- liver

\section{Introduction}

Serotonin (5-hydroxytryptamine, 5-HT) is a monoamine that mediates a range of central and peripheral functions. It is synthesized from the essential amino acid tryptophan by the sequential actions of the rate-limiting enzyme tryptophan hydroxylase (TPH) and aromatic acid decarboxylase (AADC). Most 5-HT is degraded by monoamine oxidase (MAO) to 5-hydroxyindole aldehyde, which is subsequently metabolized to 5-hydroxyindoleacetic acid (5-HIAA) by aldehyde dehydrogenase (Keszthelyi et al. 2009). In vertebrates, two isoforms of TPH exhibit mutually exclusive tissue expression patterns, TPH1 in peripheral non-neuronal tissues and TPH2 in neurons of the central and enteric nervous systems (Walther et al. 2003a, Zhang et al. 2004). Because 5-HT cannot cross the blood-brain barrier, central and peripheral 5-HT systems are functionally separate (Berger et al. 2009). By acting as a neurotransmitter in the CNS, 5-HT regulates various physiological functions, including mood (Young \& Leyton 2002), sleepwake behavior (Monti 2011), appetite (Tecott et al. 1995), and energy expenditure (McGlashon et al. 2015).

Most of the 5-HT in the periphery is synthesized by enterochromaffin cells in the gut (Erspamer \& Asero 1952, Bertaccini 1960). Gut-derived 5-HT acts locally in the gastrointestinal tract or enters the circulation. Once released from the gut, 5-HT is taken up by platelets and sequestered into their dense granules via vesicular monoamine transporters (VMAT), with the remaining free 5-HT in portal blood being primarily metabolized in the liver. Thus, $>95 \%$ of 5 -HT is stored in platelets, 
with free 5-HT levels being low in peripheral blood (Holmsen 1989, Richter et al. 1989, El-Merahbi et al. 2015). Circulating platelets secrete 5-HT in response to stimuli and lead to blood coagulation (Lopez-Vilchez et al. 2009), liver regeneration (Lesurtel et al. 2006), and liver inflammation (Lang et al. 2008). In addition to the gut, 5 -HT is synthesized in other peripheral tissues, including pancreatic $\beta$-cells (Paulmann et al. 2009, Kim et al. 2010), adipocytes (Stunes et al. 2011), and osteoclasts (ChabbiAchengli et al. 2012). Therefore, 5-HT availability in peripheral tissues is dependent on the combination of local 5-HT production, free 5-HT levels in the circulation, and amount of 5-HT released by platelets.

The biological effects of 5-HT are due primarily to its binding to 5-HT receptors (HTR) in target tissues. To date, at least 14 HTRs classified into seven families have been identified. Except for HTR3, a ligand-gated ion channel, most HTRs belong to the G-proteincoupled receptor (GPCR) superfamily, with each HTR family showing distinct intracellular signaling pathways (Noda et al. 2004, Berger et al. 2009). 5-HT can also act in a receptor-independent manner via 'serotonylation', in which 5-HT covalently binds to proteins in various cell types (Walther et al. 2003b, Paulmann et al. 2009, Watts et al. 2009, Penumatsa et al. 2014a,b, Wang et al. 2016, Al-Zoairy et al. 2017, Bader 2019).

This review discusses the roles of peripheral 5-HT in the tissue-specific regulation of energy metabolism, the mechanism by which dysfunctional peripheral 5-HT signaling can progress to metabolic diseases, and how peripheral 5-HT signaling could be a therapeutic target in patients with metabolic diseases.

\section{Metabolic roles of 5-HT in pancreatic $\beta$-cells}

Maintenance of glucose homeostasis requires an adequate $\beta$-cell mass and proper insulin secretion in response to glucose. 5-HT was shown to be secreted by $\beta$-cells upon stimulation with glucose and/or other stimuli, and the location of 5-HT inside $\beta$-cell granules has been determined (Ekholm et al. 1971, Gylfe 1978, Zhang et al. 2017). Recent transcriptomic analyses of human islets and purified human $\beta$-cells revealed that the genes encoding 5 -HT synthesizing enzymes (TPH1, TPH2, and DDC) and 15 HTRs are expressed in human islets, with HTR2B being the most highly expressed HTR-encoding gene. TPH1 is expressed in human $\beta$-cells, with the amount expressed during fetal development being greater than during adulthood (Bennet et al. 2015, Blodgett et al. 2015).
Moreover, both 5-HT and HTR2B protein are present in $\beta$-cells (Blodgett et al. 2015).

Similar to humans, 5-HT is barely detected by immunostaining in pancreatic $\beta$-cells of adult mice, because tissue 5-HT levels are low in pancreatic islets. However, the genes encoding 5-HT synthesizing enzymes, including Tph1, are expressed in rodent $\beta$-cells (Kim et al. 2010). Large amounts of 5-HT are produced and can be readily detected in $\beta$-cells during the perinatal period and pregnancy (Kim et al. 2010, Ohta et al. 2011). During these two periods, $\beta$-cells actively proliferate and their mass increases, suggesting that 5-HT may contribute to the physiological regulation of $\beta$-cell mass (Kim et al. 2010, Schraenen et al. 2010, Ohta et al. 2011).

Insulin resistance develops in pregnant females to increase nutrient flow to the fetus, and pancreatic $\beta$-cells compensates for this physiological insulin resistance by increasing their mass and insulin secretion (Van Assche et al. 1978, Parsons et al. 1992, Huang et al. 2009). Placental lactogen (PL) binds to prolactin receptor (PRLR) and induces STAT5 phosphorylation to stimulate Tph1 expression, thereby inducing the massive production of 5-HT in $\beta$-cells during pregnancy (Kim et al. 2010, Schraenen et al. 2010, Iida et al. 2015). Inhibition of 5-HT synthesis using a tryptophan-free diet or a TPH inhibitor reduced $\beta$-cell proliferation, resulting in the failure of compensatory expansion of $\beta$-cell mass and impairing glucose tolerance during pregnancy (Kim et al. 2010).

Because $\beta$-cell production of 5 -HT persists until the end of lactation, the dynamic changes in $\beta$-cell mass during gestation and lactation could not be solely due to increases in 5-HT production. Gene expression profiling of HTR during pregnancy revealed that $H$ tr $2 b$ expression was upregulated during mid-gestation, a period during which $\beta$-cells actively proliferate, whereas Htr1d expression was upregulated at the end of gestation, a period during which the expanded $\beta$-cell mass returns to its pre-pregnancy level. HTR2B is a Gq protein-coupled receptor, the activation of which induces $\beta$-cell proliferation possibly via activation of AKT and/or ERK1/2 (Jain et al. 2013). Indeed, inhibition of HTR2B signaling by a selective HTR2B antagonist or $H$ tr $2 b$ knock-out decreased $\beta$-cell proliferation during pregnancy. 5-HT has also been reported to limit $\beta$-cell expansion by inducing apoptosis through the Gi proteincoupled HTR1 receptor family (Berger et al. 2015). Similarly, upregulation of Htr1d at the end of gestation and during the postpartum period was found to correlate with the cessation of $\beta$-cell proliferation and regression of $\beta$-cell mass. Thus 5-HT increases $\beta$-cell mass during mid-gestation through HTR2B and decreases $\beta$-cell mass 
at the end of gestation through HTR1D in an autocrine/ paracrine manner. During lactation, prolactin (PRL) continues to induce 5-HT production in $\beta$-cells, increasing $\beta$-cell mass through HTR2B and thereby improving longterm glycemic control in women (Moon et al. 2020a).

During the perinatal period, disruption of $T p h 1$ in $\beta$-cells resulted in their loss of 5-HT production, reducing perinatal $\beta$-cell proliferation and $\beta$-cell mass by more than $50 \%$. This reduction in $\beta$-cell mass impaired glucose tolerance in adulthood and increased susceptibility to diabetes in response to metabolic stress (Moon et al. $2020 b$ ). Furthermore, $\beta$-cell-specific Htr2b knock-out mice phenocopied $\beta$-cell-specific Tph1 knock-out mice, suggesting that HTR2B acts downstream of 5-HT in regulating perinatal $\beta$-cell proliferation. Thus, 5-HT determines adult $\beta$-cell mass by regulating perinatal $\beta$-cell proliferation through HTR2B. Unlike during pregnancy, when PL/PRL stimulates Tph1 expression in $\beta$-cells, growth hormone (GH) stimulates Tph1 expression through the growth hormone receptor (GHR)-STAT5 pathway during the perinatal period.

5-HT and 5-hydroxytryptophan (5-HTP) have been reported to stimulate insulin and/or glucagon secretion, to inhibit their secretion, or to have no effect (Lernmark 1971, Lechin et al. 1975, Pontiroli et al. 1978, Pulido et al . 1978, Lindstrom \& Sehlin 1983, Peschke et al. 1997). However, because most of these studies were performed in vitro, the interpretation of their results is limited, with the in vivo role of 5-HT remaining unclear. HTR2B is abundantly expressed in human and rodent $\beta$-cells, where it initiates the phospholipase $\mathrm{C}$ beta (PLC $\beta$ )-inositol triphosphate $\left(\mathrm{IP}_{3}\right) /$ diacylglycerol (DAG)-Ca ${ }^{2+}$ cascade. The HTR2B agonist $\alpha$-methyl serotonin maleate was shown to enhance glucose-stimulated insulin secretion in human and mouse islets by modulating $\mathrm{Ca}^{2+}$ flux and increasing the mitochondrial oxygen consumption rate (Bennet et al. 2016, Cataldo Bascunan et al. 2019). HTR2B knock-down in INS-1 cells resulted in impaired insulin secretion (Bennet et al. 2016), whereas disruption of HTR2B in adult $\beta$-cells using MIP-CreER did not affect glucose tolerance (Kim et al. 2015). Pharmacologic treatment showed that HTR2A stimulated, whereas HTR2C inhibited, insulin secretion (Zhang et al. 2013, Bennet et al. 2015).

HTR3, a ligand-gated cation channel, was found to potentiate insulin secretion during pregnancy and in response to diet-induced insulin resistance (OharaImaizumi et al. 2013, Kim et al. 2015). $\mathrm{Na}^{+}$leakage via HTR3 was shown to slightly depolarize membrane potential, increasing membrane excitability to produce an action potential (Ohara-Imaizumi et al. 2013). This resulted in impaired insulin secretion in Htr3 knock-out mice and $\beta$-cell-specific Tph1 knock-out mice, both during pregnancy and upon high fat challenge. Activation of HTR1A and 1D resulted in the inhibition of insulin secretion (Uvnas-Moberg et al. 1996, Bennet et al. 2015). Activation of HTR1F in $\alpha$-cells by LY344864 inhibited glucagon secretion and improved streptozotocininduced hyperglycemia (Almaca et al. 2016). Further studies are required to determine the functions of the HTR4-7 subfamilies.

Intracellular 5-HT may also be involved in $\beta$-cell function. Intracellular 5-HT was found to potentiate insulin secretion in Tph1 knock-out mice in vivo (Paulmann et al. 2009). Intracellular 5-HT was shown to covalently bind to the small GTPases, RAB3A and RAB27A, via 'serotonylation', with inhibition of this binding resulting in impaired insulin secretion. Intracellular 5-HT was also shown to protect $\beta$-cells from mitochondrial stress by reducing their burden of reactive oxygen species (ROS). Tryptophan and its metabolites (i.e. 5-HTP, 5-HT, and melatonin) are indole derivatives that can directly scavenge ROS (Estevao et al. 2010). Our group recently reported that 5-HT and 5-HTP in $\beta$-cells could scavenge ROS, enhancing $\beta$-cell function and survival (Moon et al. 2020a).

Overall, 5-HT plays several beneficial roles in $\beta$-cells, such that the selective loss of 5-HT function in $\beta$-cells resulted in reduced glucose tolerance in vivo. However, systemic inhibition of peripheral 5-HT synthesis resulted in different metabolic phenotypes, either impaired insulin secretion with impaired glucose tolerance (Paulmann et al. 2009), or improved insulin sensitivity with improved glucose tolerance and insulin sensitivity upon consuming a high fat diet (HFD) (Crane et al. 2015, Oh et al. 2015). Further studies are required to determine the contribution of 5-HT in different tissues.

\section{Metabolic roles of 5-HT in adipose tissues}

Adipose tissue is a dynamic metabolic organ that both stores and consumes energy. Adipose tissues can be classified into two functionally distinct types: white adipose tissue (WAT) and brown adipose tissue (BAT) (Rosen $\&$ Spiegelman 2006). More recently, a third functionally distinct type of adipocytes was identified; these cells, called beige adipocytes, are located in WAT depots but function as BAT (Wu et al. 2012). Beige adipocytes contain several lipid droplets and express uncoupling protein 1 (UCP1). 
WAT mainly acts as an energy storage reservoir in the body. In the fed state, white adipocytes absorb excess energy and store it as triglycerides, whereas, in the fasting state, white adipocytes supply energy to other organs by catabolizing triglycerides to free fatty acids and glycerol (Zechner et al.2017). Brown and beige adipocytes consume energy to generate heat and maintain optimal body temperature (Sidossis \& Kajimura 2015). Importantly, defective clearance of nutrients, increased lipolysis, and decreased thermogenesis by adipocytes contribute to the development of metabolic diseases, such as obesity, type 2 diabetes, and non-alcoholic fatty liver disease (NAFLD) (Samuel \& Shulman 2012).

Although 5-HT was shown to be present in adipose tissue (Stock \& Westermann 1963), it was unclear whether adipocytes synthesize 5-HT autonomously. Recent evidence showed that adipocytes have a functional system for 5-HT synthesis and that Tph1 expression and the amount of 5-HT increase during adipocyte differentiation (Stunes et al. 2011). Tph1 expression has been reported to be essential for the differentiation of 3T3-L1 adipocytes (Kinoshita et al. 2010). 5-HT signaling regulates multiple metabolic pathways in mature adipocytes. Htr2a expression is upregulated in hypertrophied 3T3-L1 adipocytes, with HTR2A antagonist increasing adiponectin expression in 3T3-L1 cells (Uchida-Kitajima et al. 2008). Similar findings were observed in diabetic patients, in that treatment with HTR2A antagonist increased circulating adiponectin concentrations (Yamakawa et al. 2003). In the fasting state, 5-HT induced lipolysis through HTR2B in adipocytes, mediating the phosphorylation of hormonesensitive lipase (HSL) on serine 563 and 660 residues (Sumara et al. 2012).

Inhibition of peripheral 5-HT synthesis by Tph1 knock-out or by treatment with a peripheral TPH inhibitor was found to ameliorate HFD-induced obesity by UCP1dependent thermogenic mechanisms (Crane et al. 2015, Oh et al. 2015). 5-HT inhibits both brown adipocyte differentiation and $\beta 3$-adrenergic induced thermogenic activation in a cell-autonomous manner (Crane et al. 2015, Rozenblit-Susan et al. 2018). Furthermore, HTR3 signaling in BAT may suppress BAT thermogenesis. Htr3a knock-out mice were protected from HFD-induced obesity, accompanied by thermogenic activation in BAT. During $\beta 3$ adrenergic activation, the HTR3 antagonist ondansetron increased cyclic AMP production and the phosphorylation of hormone-sensitive lipase and protein kinase A substrate in immortalized brown adipocytes (Oh et al. 2015). Similar to Tph1 knock-out mice, adipocyte-specific Tph1 knock-out mice also showed resistance to HFD-induced obesity by increasing energy expenditure (Oh et al. 2015). However, specific inhibition of 5 -HT synthesis in the gut, the major source of 5-HT in the periphery, did not protect against HFD-induced obesity (Sumara et al. 2012, Choi et al. 2018). Recently, 5-HT produced by mast cells rather than adipocytes in s.c. adipose tissue was proposed to inhibit adaptive thermogenesis by reducing PDGFR $\alpha^{+}$ adipocyte precursor proliferation and beige adipocyte differentiation (Zhang et al. 2019). Collectively, these studies indicate that regional 5-HT synthesis is critical in regulating thermogenesis in adipose tissue. Further studies are needed to determine the precise relative importance between adipocyte- and mast cell-derived 5-HT on regulating adaptive thermogenesis in s.c. adipose tissue.

\section{Metabolic roles of serotonin in liver}

The liver is a major metabolic organ that regulates circulating glucose and lipids in the body. When nutrients are in excess, hepatocytes sequester glucose and fatty acids as glycogen and triglycerides. During fasting, however, hepatocytes maintain blood glucose levels by promoting glucose release through glycogen breakdown (glycogenolysis) and de novo glucose synthesis from glycerol and amino acids (gluconeogenesis).

Hepatocytes do not themselves synthesize 5-HT, but have a functional serotonergic system. 5-HT acting on the liver is derived from the gut (free 5-HT) or platelets, depending on physiological conditions (Lesurtel et al. 2006, Sumara et al. 2012). 5-HT regulates glucose metabolism in hepatocytes. During fasting, gut-derived 5-HT promotes gluconeogenesis in hepatocytes by increasing the activity of two rate-limiting enzymes, fructose 1,6-bisphosphatase (FBPase) and glucose 6-phosphatase (G6pase), through HTR2B. In addition, hepatocyte HTR2B signaling hampers glucose uptake by promoting the degradation of glucose transporter 2 (GLUT2) (Sumara et al. 2012). 5-HT signaling also regulates lipid metabolism in hepatocytes. 5-HT has an additive effect on lipid accumulation in fatty acid treated hepatocytes (Osawa et al. 2011). Genetic or pharmacologic inhibition of HTR3 signaling in rodent models of diet-induced obesity reduces hepatic lipid accumulation (Haub et al. 2011, Namkung et al. 2018). Under HFD-fed conditions, inhibiting gutderived 5-HT synthesis ameliorates hepatic steatosis by reducing hepatic HTR2A signaling (Choi et al. 2018). Both gut-specific Tph1 and hepatocyte-specific Htr2a knock-out mice are resistant to HFD-induced hepatic steatosis via the downregulation of hepatic lipogenesis. 
These effects are independent of UCP1-dependent thermogenesis in brown and beige adipose tissues.

Hepatic steatosis is an early pathological event in NAFLD, which can progress to non-alcoholic steatohepatitis, liver cirrhosis, and hepatocellular carcinoma (Friedman et al. 2018). Advanced liver fibrosis is a key prognostic factor in NAFLD (Dulai et al. 2017), with hepatic stellate cells (HSCs) being the principal sources of myofibroblasts in liver fibrosis (Mederacke et al. 2013). 5-HT signaling has a direct role in regulating HSC activation and resolution. 5-HT synergizes with plateletderived growth factor to stimulate HSC proliferation. Furthermore, antagonizing HTR2 signaling on HSCs suppresses their proliferation and increases their rate of apoptosis (Ruddell et al. 2006). In agreement with these results, HTR2A antagonists were shown to inhibit viability and wound healing in LX-2 human hepatic stellate cell lines (Kim et al. 2013). HTR2B signaling activates HSCs by inducing the expression of transforming growth factor $\beta 1$ (TGF $\beta 1$ ) through a signaling pathway involving mitogenactivated protein kinase 1 (MAPK1) and the transcription factor JunD (Ebrahimkhani et al. 2011).

\section{Possible metabolic roles of serotonin in other peripheral cells}

Chronic inflammation, especially in adipose tissue and liver, has been shown to promote insulin resistance (Hotamisligil 2017). In addition, pancreatic islet inflammation was shown to result in the development of $\beta$-cell dysfunction (Eguchi \& Nagai 2017). Peripheral 5 -HT is involved in inflammatory conditions by acting on various immune cells (Schoenichen et al. 2019), including its promotion of neutrophil adhesion and recruitment during acute inflammation (Duerschmied et al. 2013). Tph1 knock-out mice exhibit reduced allergic airway inflammation due to the defective Th2-priming capacity of bone marrow dendritic cells (Durk et al. 2013). Peripheral 5-HT also prevents the development of experimental colitis by downregulating macrophage infiltration and their subsequent production of proinflammatory cytokines (Ghia et al. 2009). 5-HT was shown to mediate proinflammatory activities, but also inhibits proinflammatory cytokine release and promotes M2 polarization in human macrophages (de las Casas-Engel et al. 2013). Additional studies are needed to determine how 5-HT regulates energy metabolism through its effects on immune cells.
Skeletal muscle is a metabolic organ that regulates whole-body glucose homeostasis through glucose uptake, mainly by GLUT4. HTR2A is localized exclusively in plasma membranes of both white and red muscle fibers, and 5-HT directly stimulates glucose uptake through HTR2A (Hajduch et al. 1999a,b). Moreover, 5-HT stimulates glucose disposal by upregulating 6-phosphofructo-1kinase (PFK) activity through HTR2A (Coelho et al. 2007). Because of the lack of well-designed in vivo studies, the physiological relevance of glucose disposal by peripheral 5-HT is uncertain, and further studies are needed.

\section{Targeting peripheral serotonin signaling pathways in the treatment of metabolic diseases}

Drugs modulating 5-HT signaling pathways are used to treat various human diseases. For example, selective serotonin reuptake inhibitors are widely used to treat mental disorders (Fournier et al. 2010), the peripheral $\mathrm{TPH}$ inhibitor telotristat ethyl is used to treat carcinoid syndrome (Lyseng-Williamson 2018), the HTR2A antagonist sarpogrelate hydrochloride is used to treat peripheral arterial disease (Miyazaki et al. 2007), the HTR2C agonist lorcaserin is used to treat obesity (Bohula et al. 2018), the HTR3 antagonist ondansetron is used to treat nausea and vomiting (Tramer et al. 1997), and the HTR4 agonist prucalopride is used to treat chronic constipation (Omer \& Quigley 2017).

In humans, plasma 5-HT concentrations are higher in obese than in non-obese subjects, with 5-HT concentrations being positively correlated with BMI and glycated hemoglobin (HbA1c) concentration (Young et al. 2018). Similarly, plasma 5-HIAA concentrations are higher in subjects with than without metabolic syndrome and are positively correlated with fasting plasma glucose concentration (Fukui et al. 2012). Because peripheral 5-HT signaling pathways regulate energy metabolism in various metabolic organs, targeting peripheral 5-HT signaling pathways may be a novel strategy for treating metabolic diseases. The peripheral TPH inhibitor LP-533401 was shown to ameliorate glucose intolerance in a rodent model of HFD-induced obesity without altering body weight gain (Sumara et al. 2012). LP-533401 was also shown to prevent diet-induced obesity by activating BAT and beige adipose tissue thermogenesis (Crane et al. 2015, Oh et al. 2015). Administration of the HTR2A antagonist sarpogrelate hydrochloride was found to prevent the 


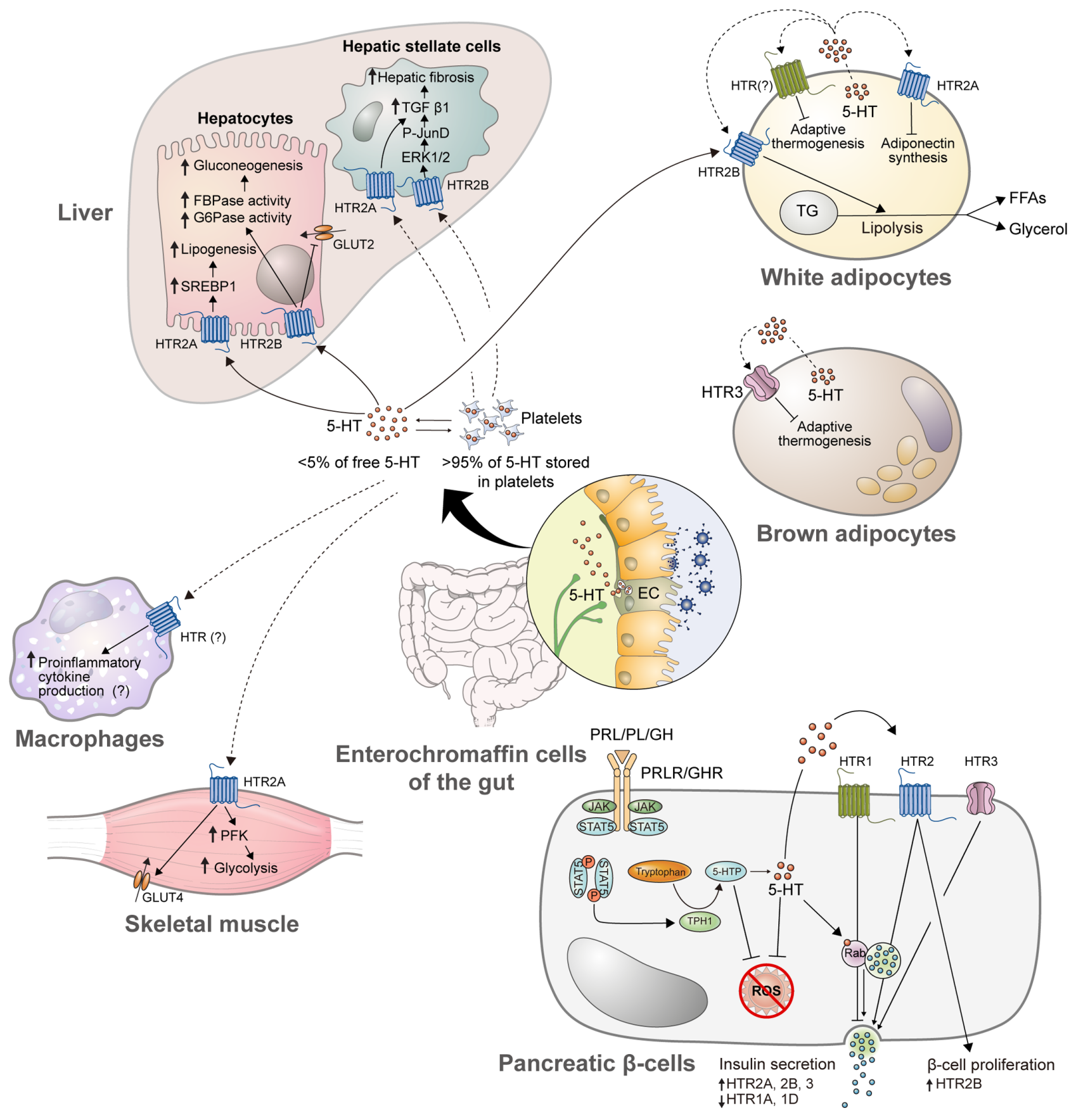

Figure 1

Roles of peripheral serotonin in the regulation of energy metabolism. Most peripheral serotonin (5-hydroxytryptamine, 5-HT) is synthesized by enterochromaffin cells (EC) in the gut, where it acts locally or enters the circulation. In the bloodstream, most 5-HT is taken up by platelets, with free 5-HT levels being low in peripheral blood. In addition to the gut, $5-\mathrm{HT}$ is synthesized in other peripheral metabolic tissues, including pancreatic $\beta$-cells and adipocytes. 5-HT directly regulates energy metabolism in metabolic tissues. It promotes proliferation and insulin secretion in pancreatic $\beta$-cells, induces lipolysis and suppresses UCP1-dependent adaptive thermogenesis in adipocytes, induces lipogenesis and gluconeogenesis while suppressing glucose uptake in hepatocytes, and regulates activation and resolution in hepatic stellate cells (HSCs). 5-HTP, 5-hydroxytryptophan; HTR, 5-HT receptors; PRL, prolactin; PL, placental lactogen; GH, growth hormone; PRLR, prolactin receptor; GHR, growth hormone receptor; JAK, janus kinase; STAT5, signal transducer and activator of transcription 5; GLUT, glucose transporter; PFK, phosphofructokinase; FBPase, fructose 1,6-bisphosphatase; G6Pase, glucose 6-phosphatase; TGF $\beta 1$, transforming growth factor $\beta 1$; ERK1/2, extracellular signal regulated kinase 1/2; FFA, free fatty acid. 
development of HFD-induced hepatic steatosis (Choi et al. 2018) and to prevent hepatic inflammation and fibrosis in a thioacetamide-induced liver fibrosis model (Kim et al. 2013). Similarly, the HTR2B antagonist SB-204741 was shown to prevent hepatic fibrosis in a carbon tetrachloride- and bile duct ligation-induced liver fibrosis model (Ebrahimkhani et al. 2011). These findings indicate that peripheral TPH inhibitors may be used as drugs targeting obesity and/or metabolic syndrome (Matthes \& Bader 2018), whereas HTR2A/2B antagonists might serve as drugs targeting NAFLD. However, possible deleterious effects on glucose homeostasis of TPH1 inhibition in pancreatic $\beta$-cells in specific time points, such as perinatal, pregnancy, and lactation periods, should be carefully considered.

\section{Conclusions}

Although most 5-HT in the body is synthesized at the periphery, most studies have focused on the mechanism by which central 5-HT regulates mood and behavior. More recently, studies have analyzed the physiological functions of peripheral 5-HT, in particular, its role in regulating energy metabolism in multiple metabolic organs. 5 -HT directly promotes pancreatic $\beta$-cell proliferation and secretion of insulin. 5-HT induces lipolysis and suppresses UCP1-dependent adaptive thermogenesis in adipocytes. In the liver, 5-HT induces lipogenesis and gluconeogenesis, while suppressing glucose uptake in hepatocytes. 5-HT also promotes HSC activation and is involved in the development of hepatic fibrosis. 5-HT may regulate energy metabolism by directly acting on immune cells and skeletal muscle. The findings in this review are summarized in Fig. 1. Based on these findings, inhibitors of peripheral 5-HT synthesis and/or HTR signaling may have potential as novel drugs targeting obesity, metabolic syndrome, and NAFLD.

Peripheral 5-HT signaling is a complex process. 5-HT is synthesized at multiple sites, signals through auto-, para-, and endocrine pathways, and binds to at least 14 receptors. To date, studies of peripheral 5-HT signaling were performed using whole-body knock-out mice or HTR agonists/antagonists. However, these strategies have limitations in unraveling the tissue-specific effects of 5-HT signaling in vivo. More detailed studies of the various roles of 5-HT in regulating energy metabolism using tissue-specific knock-out strategies may result in better understanding of the complex biology of this biogenic amine.

\section{Declaration of interest}

The authors declare that there is no conflict of interest that could be perceived as prejudicing the impartiality of this review.

\section{Funding}

This work was supported by grants from the National Research Foundation (NRF) of Korea (grant numbers: NRF-2017H1A2A1042095 to Joon Ho Moon and NRF-2015M3A9B3028218, NRF-2016M3A9B6902871, and NRF-2018R1A2A3074646 to Hail Kim) and the Health Fellowship Foundation (to Joon Ho Moon).

\section{References}

Almaca J, Molina J, Menegaz D, Pronin AN, Tamayo A, Slepak V, Berggren PO \& Caicedo A 2016 Human beta cells produce and release serotonin to inhibit glucagon secretion from alpha cells. Cell Reports 17 3281-3291. (https://doi.org/10.1016/j.celrep.2016.11.072)

Al-Zoairy R, Pedrini MT, Khan MI, Engl J, Tschoner A, Ebenbichler C, Gstraunthaler G, Salzmann K, Bakry R \& Niederwanger A 2017 Serotonin improves glucose metabolism by serotonylation of the small GTPase Rab4 in L6 skeletal muscle cells. Diabetology and Metabolic Syndrome 9 1. (https://doi.org/10.1186/s13098-016-0201-1)

Bader M 2019 Serotonylation: serotonin signaling and epigenetics. Frontiers in Molecular Neuroscience 12 288. (https://doi.org/10.3389/ fnmol.2019.00288)

Bennet H, Balhuizen A, Medina A, Dekker Nitert M, Ottosson Laakso E, Essen S, Spegel P, Storm P, Krus U, Wierup N, et al. 2015 Altered serotonin (5-HT) $1 \mathrm{D}$ and $2 \mathrm{~A}$ receptor expression may contribute to defective insulin and glucagon secretion in human type 2 diabetes. Peptides 71 113-120. (https://doi.org/10.1016/j.peptides.2015.07.008)

Bennet H, Mollet IG, Balhuizen A, Medina A, Nagorny C, Bagge A, Fadista J, Ottosson-Laakso E, Vikman P, Dekker-Nitert M, et al. 2016 Serotonin (5-HT) receptor $2 \mathrm{~b}$ activation augments glucose-stimulated insulin secretion in human and mouse islets of Langerhans. Diabetologia 59 744-754. (https://doi.org/10.1007/s00125-015-3847-6)

Berger M, Gray JA \& Roth BL 2009 The expanded biology of serotonin. Annual Review of Medicine 60 355-366. (https://doi.org/10.1146/ annurev.med.60.042307.110802)

Berger M, Scheel DW, Macias H, Miyatsuka T, Kim H, Hoang P, Ku GM, Honig G, Liou A, Tang Y, et al. 2015 Galphai/o-coupled receptor signaling restricts pancreatic beta-cell expansion. PNAS 112 2888-2893. (https://doi.org/10.1073/pnas.1319378112)

Bertaccini G 1960 Tissue 5-hydroxytryptamine and urinary 5-hydroxyindoleacetic acid after partial or total removal of the gastrointestinal tract in the rat. Journal of Physiology 153 239-249. (https:// doi.org/10.1113/jphysiol.1960.sp006532)

Blodgett DM, Nowosielska A, Afik S, Pechhold S, Cura AJ, Kennedy NJ, Kim S, Kucukural A, Davis RJ, Kent SC, et al. 2015 Novel observations from next-generation RNA sequencing of highly purified human adult and fetal islet cell subsets. Diabetes 64 3172-3181. (https://doi. org/10.2337/db15-0039)

Bohula EA, Wiviott SD, McGuire DK, Inzucchi SE, Kuder J, Im K, Fanola CL, Qamar A, Brown C, Budaj A, et al. 2018 Cardiovascular safety of lorcaserin in overweight or obese patients. New England Journal of Medicine 379 1107-1117. (https://doi.org/10.1056/ NEJMoa1808721)

Cataldo Bascunan LR, Lyons C, Bennet H, Artner I \& Fex M 2019 Serotonergic regulation of insulin secretion. Acta Physiologica 225 e13101. (https://doi.org/10.1111/apha.13101)

Chabbi-Achengli Y, Coudert AE, Callebert J, Geoffroy V, Cote F, Collet C $\&$ de Vernejoul MC 2012 Decreased osteoclastogenesis in 
serotonin-deficient mice. PNAS 109 2567-2572. (https://doi. org/10.1073/pnas.1117792109)

Choi W, Namkung J, Hwang I, Kim H, Lim A, Park HJ, Lee HW, Han KH, Park S, Jeong JS, et al. 2018 Serotonin signals through a gut-liver axis to regulate hepatic steatosis. Nature Communications 9 4824. (https:// doi.org/10.1038/s41467-018-07287-7)

Coelho WS, Costa KC \& Sola-Penna M 2007 Serotonin stimulates mouse skeletal muscle 6-phosphofructo-1-kinase through tyrosinephosphorylation of the enzyme altering its intracellular localization. Molecular Genetics and Metabolism 92 364-370. (https://doi. org/10.1016/j.ymgme.2007.07.010)

Crane JD, Palanivel R, Mottillo EP, Bujak AL, Wang H, Ford RJ, Collins A, Blumer RM, Fullerton MD, Yabut JM, et al. 2015 Inhibiting peripheral serotonin synthesis reduces obesity and metabolic dysfunction by promoting brown adipose tissue thermogenesis. Nature Medicine 21 166-172. (https://doi.org/10.1038/nm.3766)

de las Casas-Engel M, Dominguez-Soto A, Sierra-Filardi E, Bragado R, Nieto C, Puig-Kroger A, Samaniego R, Loza M, Corcuera MT, Gomez-Aguado F, et al. 2013 Serotonin skews human macrophage polarization through HTR2B and HTR7. Journal of Immunology 190 2301-2310. (https://doi.org/10.4049/jimmunol.1201133)

Duerschmied D, Suidan GL, Demers M, Herr N, Carbo C, Brill A, Cifuni SM, Mauler M, Cicko S, Bader M, et al. 2013 Platelet serotonin promotes the recruitment of neutrophils to sites of acute inflammation in mice. Blood 121 1008-1015. (https://doi. org/10.1182/blood-2012-06-437392)

Dulai PS, Singh S, Patel J, Soni M, Prokop LJ, Younossi Z, Sebastiani G, Ekstedt M, Hagstrom H, Nasr P, et al. 2017 Increased risk of mortality by fibrosis stage in nonalcoholic fatty liver disease: systematic review and meta-analysis. Hepatology 65 1557-1565. (https://doi. org/10.1002/hep.29085)

Durk T, Duerschmied D, Muller T, Grimm M, Reuter S, Vieira RP, Ayata K, Cicko S, Sorichter S, Walther DJ, et al. 2013 Production of serotonin by tryptophan hydroxylase 1 and release via platelets contribute to allergic airway inflammation. American Journal of Respiratory and Critical Care Medicine 187 476-485. (https://doi.org/10.1164/ rccm.201208-1440OC)

Ebrahimkhani MR, Oakley F, Murphy LB, Mann J, Moles A, Perugorria MJ, Ellis E, Lakey AF, Burt AD, Douglass A, et al. 2011 Stimulating healthy tissue regeneration by targeting the 5-HT(2). Nature Medicine 17 1668-1673. (https://doi.org/10.1038/nm.2490)

Eguchi K \& Nagai R 2017 Islet inflammation in type 2 diabetes and physiology. Journal of Clinical Investigation 127 14-23. (https://doi. org/10.1172/JCI88877)

Ekholm R, Ericson LE \& Lundquist I 1971 Monoamines in the pancreatic islets of the mouse. Subcellular localization of 5-hydroxytryptamine by electron microscopic autoradiography. Diabetologia 7 339-348. (https://doi.org/10.1007/bf01219468)

El-Merahbi R, Loffler M, Mayer A \& Sumara G 2015 The roles of peripheral serotonin in metabolic homeostasis. FEBS Letters $\mathbf{5 8 9}$ 1728-1734. (https://doi.org/10.1016/j.febslet.2015.05.054)

Erspamer V \& Asero B 1952 Identification of enteramine, the specific hormone of the enterochromaffin cell system, as 5-hydroxytryptamine. Nature 169 800-801. (https://doi. org/10.1038/169800b0)

Estevao MS, Carvalho LC, Ribeiro D, Couto D, Freitas M, Gomes A, Ferreira LM, Fernandes E \& Marques MM 2010 Antioxidant activity of unexplored indole derivatives: synthesis and screening. European Journal of Medicinal Chemistry 45 4869-4878. (https://doi. org/10.1016/j.ejmech.2010.07.059)

Fournier JC, DeRubeis RJ, Hollon SD, Dimidjian S, Amsterdam JD, Shelton RC \& Fawcett J 2010 Antidepressant drug effects and depression severity: a patient-level meta-analysis. JAMA 303 47-53. (https://doi.org/10.1001/jama.2009.1943)

Friedman SL, Neuschwander-Tetri BA, Rinella M \& Sanyal AJ 2018 Mechanisms of NAFLD development and therapeutic strategies.
Nature Medicine 24 908-922. (https://doi.org/10.1038/s41591-0180104-9)

Fukui M, Tanaka M, Toda H, Asano M, Yamazaki M, Hasegawa G, Imai S \& Nakamura N 2012 High plasma 5-hydroxyindole-3-acetic acid concentrations in subjects with metabolic syndrome. Diabetes Care $\mathbf{3 5}$ 163-167. (https://doi.org/10.2337/dc11-1619)

Ghia JE, Li N, Wang H, Collins M, Deng Y, El-Sharkawy RT, Cote F, Mallet J \& Khan WI 2009 Serotonin has a key role in pathogenesis of experimental colitis. Gastroenterology 137 1649-1660. (https://doi. org/10.1053/j.gastro.2009.08.041)

Gylfe E 1978 Association between 5-hydroxytryptamine release and insulin secretion. Journal of Endocrinology $\mathbf{7 8}$ 239-248. (https://doi. org/10.1677/joe.0.0780239)

Hajduch E, Dombrowski L, Darakhshan F, Rencurel F, Marette A $\&$ Hundal HS 1999a Biochemical localisation of the 5-HT2A (serotonin) receptor in rat skeletal muscle. Biochemical and Biophysical Research Communications 257 369-372. (https://doi.org/10.1006/ bbrc.1999.0471)

Hajduch E, Rencurel F, Balendran A, Batty IH, Downes CP \& Hundal HS $1999 b$ Serotonin (5-hydroxytryptamine), a novel regulator of glucose transport in rat skeletal muscle. Journal of Biological Chemistry 274 13563-13568. (https://doi.org/10.1074/jbc.274.19.13563)

Haub S, Ritze Y, Ladel I, Saum K, Hubert A, Spruss A, Trautwein C \& Bischoff SC 2011 Serotonin receptor type 3 antagonists improve obesity-associated fatty liver disease in mice. Journal of Pharmacology and Experimental Therapeutics 339 790-798. (https://doi.org/10.1124/ jpet.111.181834)

Holmsen H 1989 Physiological functions of platelets. Annals of Medicine 21 23-30. (https://doi.org/10.3109/07853898909149178)

Hotamisligil GS 2017 Inflammation, metaflammation and immunometabolic disorders. Nature 542 177-185. (https://doi. org/10.1038/nature21363)

Huang C, Snider F \& Cross JC 2009 Prolactin receptor is required for normal glucose homeostasis and modulation of beta-cell mass during pregnancy. Endocrinology 150 1618-1626. (https://doi.org/10.1210/ en.2008-1003)

Iida H, Ogihara T, Min MK, Hara A, Kim YG, Fujimaki K, Tamaki M, Fujitani Y, Kim H \& Watada H 2015 Expression mechanism of tryptophan hydroxylase 1 in mouse islets during pregnancy. Journal of Molecular Endocrinology 55 41-53. (https://doi.org/10.1530/JME-140299)

Jain S, Ruiz de Azua I, Lu H, White MF, Guettier JM \& Wess J 2013 Chronic activation of a designer $\mathrm{G}(\mathrm{q})$-coupled receptor improves beta cell function. Journal of Clinical Investigation 123 1750-1762. (https:// doi.org/10.1172/JCI66432)

Keszthelyi D, Troost FJ \& Masclee AA 2009 Understanding the role of tryptophan and serotonin metabolism in gastrointestinal function. Neurogastroenterology and Motility 21 1239-1249. (https://doi. org/10.1111/j.1365-2982.2009.01370.x)

Kim H, Toyofuku Y, Lynn FC, Chak E, Uchida T, Mizukami H, Fujitani Y, Kawamori R, Miyatsuka T, Kosaka Y, et al. 2010 Serotonin regulates pancreatic beta cell mass during pregnancy. Nature Medicine $\mathbf{1 6}$ 804-808. (https://doi.org/10.1038/nm.2173)

Kim DC, Jun DW, Kwon YI, Lee KN, Lee HL, Lee OY, Yoon BC, Choi HS \& Kim EK 2013 5-HT2A receptor antagonists inhibit hepatic stellate cell activation and facilitate apoptosis. Liver International 33 535-543. (https://doi.org/10.1111/liv.12110)

Kim K, Oh CM, Ohara-Imaizumi M, Park S, Namkung J, Yadav VK, Tamarina NA, Roe MW, Philipson LH, Karsenty G, et al. 2015 Functional role of serotonin in insulin secretion in a diet-induced insulin-resistant state. Endocrinology 156 444-452. (https://doi. org/10.1210/en.2014-1687)

Kinoshita M, Ono K, Horie T, Nagao K, Nishi H, Kuwabara Y, TakanabeMori R, Hasegawa K, Kita T \& Kimura T 2010 Regulation of adipocyte differentiation by activation of serotonin (5-HT) receptors 5-HT2AR and 5-HT2CR and involvement of microRNA-448-mediated repression https://joe.bioscientifica.com https://doi.org/10.1530/JOE-19-0546 (c) 2020 Society for Endocrinology Published by Bioscientifica Ltd. Printed in Great Britain 
of KLF5. Molecular Endocrinology 24 1978-1987. (https://doi. org/10.1210/me.2010-0054)

Lang PA, Contaldo C, Georgiev P, El-Badry AM, Recher M, Kurrer M, Cervantes-Barragan L, Ludewig B, Calzascia T, Bolinger B, et al. 2008 Aggravation of viral hepatitis by platelet-derived serotonin. Nature Medicine 14 756-761. (https://doi.org/10.1038/nm1780)

Lechin F, Coll-Garcia E, Van Der Dijs B, Pena F, Bentolila A \& Rivas C 1975 The effect of serotonin (5-HT) on insulin secretion. Acta Physiologica Latino Americana 25 339-346.

Lernmark A 1971 The significance of 5-hydroxytryptamine for insulin secretion in the mouse. Hormone and Metabolic Research 3 305-309. (https://doi.org/10.1055/s-0028-1094131)

Lesurtel M, Graf R, Aleil B, Walther DJ, Tian Y, Jochum W, Gachet C, Bader M \& Clavien PA 2006 Platelet-derived serotonin mediates liver regeneration. Science 312 104-107. (https://doi.org/10.1126/ science.1123842)

Lindstrom P \& Sehlin J 1983 Mechanisms underlying the effects of 5-hydroxytryptamine and 5-hydroxytryptophan in pancreatic islets. A proposed role for L-aromatic amino acid decarboxylase. Endocrinology 112 1524-1529. (https://doi.org/10.1210/endo-112-4-1524)

Lopez-Vilchez I, Diaz-Ricart M, White JG, Escolar G \& Galan AM 2009 Serotonin enhances platelet procoagulant properties and their activation induced during platelet tissue factor uptake. Cardiovascular Research 84 309-316. (https://doi.org/10.1093/cvr/cvp205)

Lyseng-Williamson KA 2018 Telotristat ethyl: a review in carcinoid syndrome diarrhoea. Drugs 78 941-950. (https://doi.org/10.1007/ s40265-018-0935-1)

Matthes S \& Bader M 2018 Peripheral serotonin synthesis as a new drug target. Trends in Pharmacological Sciences 39 560-572. (https://doi. org/10.1016/j.tips.2018.03.004)

McGlashon JM, Gorecki MC, Kozlowski AE, Thirnbeck CK, Markan KR, Leslie KL, Kotas ME, Potthoff MJ, Richerson GB \& Gillum MP 2015 Central serotonergic neurons activate and recruit thermogenic brown and beige fat and regulate glucose and lipid homeostasis. Cell Metabolism 21 692-705. (https://doi.org/10.1016/j. cmet.2015.04.008)

Mederacke I, Hsu CC, Troeger JS, Huebener P, Mu X, Dapito DH, Pradere JP \& Schwabe RF 2013 Fate tracing reveals hepatic stellate cells as dominant contributors to liver fibrosis independent of its aetiology. Nature Communications 4 2823. (https://doi.org/10.1038/ncomms3823)

Miyazaki M, Higashi Y, Goto C, Chayama K, Yoshizumi M, Sanada H, Orihashi K \& Sueda T 2007 Sarpogrelate hydrochloride, a selective 5-HT2A antagonist, improves vascular function in patients with peripheral arterial disease. Journal of Cardiovascular Pharmacology 49 221-227. (https://doi.org/10.1097/FJC.0b013e3180325af3)

Monti JM 2011 Serotonin control of sleep-wake behavior. Sleep Medicine Reviews 15 269-281. (https://doi.org/10.1016/j.smrv.2010.11.003)

Moon JH, Kim H, Kim H, Park J, Choi W, Choi W, Hong HJ, Ro H-J, Jun S, Choi SH, et al. 2020a Lactation improves pancreatic $\beta$ cell mass and function through serotonin production. Science Translational Medicine [in press].

Moon JH, Kim YG, Kim K, Osonoi S, Wang S, Saunders DC, Wang J, Yang K, Kim H, Lee J, et al. 2020b Serotonin regulates adult beta-cell mass by stimulating perinatal beta-cell proliferation. Diabetes 69 205-214. (https://doi.org/10.2337/db19-0546)

Namkung J, Shong KE, Kim H, Oh CM, Park S \& Kim H 2018 Inhibition of serotonin synthesis induces negative hepatic lipid balance. Diabetes and Metabolism Journal 42 233-243. (https://doi.org/10.4093/ dmj.2017.0084)

Noda M, Higashida H, Aoki S \& Wada K 2004 Multiple signal transduction pathways mediated by 5-HT receptors. Molecular Neurobiology 29 31-39. (https://doi.org/10.1385/MN:29:1:31)

Oh CM, Namkung J, Go Y, Shong KE, Kim K, Kim H, Park BY, Lee HW, Jeon YH, Song J, et al. 2015 Regulation of systemic energy homeostasis by serotonin in adipose tissues. Nature Communications 6 6794. (https://doi.org/10.1038/ncomms7794)
Ohara-Imaizumi M, Kim H, Yoshida M, Fujiwara T, Aoyagi K, Toyofuku Y, Nakamichi Y, Nishiwaki C, Okamura T, Uchida T, et al. 2013 Serotonin regulates glucose-stimulated insulin secretion from pancreatic beta cells during pregnancy. PNAS 110 19420-19425. (https://doi.org/10.1073/pnas.1310953110)

Ohta Y, Kosaka Y, Kishimoto N, Wang J, Smith SB, Honig G, Kim H, Gasa RM, Neubauer N, Liou A, et al. 2011 Convergence of the insulin and serotonin programs in the pancreatic beta-cell. Diabetes $\mathbf{6 0}$ 3208-3216. (https://doi.org/10.2337/db10-1192)

Omer A \& Quigley EMM 2017 An update on prucalopride in the treatment of chronic constipation. Therapeutic Advances in Gastroenterology 10 877-887. (https://doi.org/10.1177/17562 83X17734809)

Osawa Y, Kanamori H, Seki E, Hoshi M, Ohtaki H, Yasuda Y, Ito H, Suetsugu A, Nagaki M, Moriwaki H, et al. 2011 L-tryptophanmediated enhancement of susceptibility to nonalcoholic fatty liver disease is dependent on the mammalian target of rapamycin. Journal of Biological Chemistry 286 34800-34808. (https://doi.org/10.1074/jbc. M111.235473)

Parsons JA, Brelje TC \& Sorenson RL 1992 Adaptation of islets of Langerhans to pregnancy: increased islet cell proliferation and insulin secretion correlates with the onset of placental lactogen secretion. Endocrinology 130 1459-1466. (https://doi.org/10.1210/ endo.130.3.1537300)

Paulmann N, Grohmann M, Voigt JP, Bert B, Vowinckel J, Bader M, Skelin M, Jevsek M, Fink H, Rupnik M, et al. 2009 Intracellular serotonin modulates insulin secretion from pancreatic beta-cells by protein serotonylation. PLoS Biology 7 e1000229. (https://doi. org/10.1371/journal.pbio.1000229)

Penumatsa K, Abualkhair S, Wei L, Warburton R, Preston I, Hill NS, Watts SW, Fanburg BL \& Toksoz D 2014a Tissue transglutaminase promotes serotonin-induced AKT signaling and mitogenesis in pulmonary vascular smooth muscle cells. Cellular Signalling $\mathbf{2 6}$ 2818-2825. (https://doi.org/10.1016/j.cellsig.2014.09.002)

Penumatsa KC, Toksoz D, Warburton RR, Hilmer AJ, Liu T, Khosla C, Comhair SA \& Fanburg BL 2014b Role of hypoxia-induced transglutaminase 2 in pulmonary artery smooth muscle cell proliferation. American Journal of Physiology: Lung Cellular and Molecular Physiology 307 L576-L585. (https://doi.org/10.1152/ ajplung.00162.2014)

Peschke E, Peschke D, Hammer T \& Csernus V 1997 Influence of melatonin and serotonin on glucose-stimulated insulin release from perifused rat pancreatic islets in vitro. Journal of Pineal Research 23 156-163. (https://doi.org/10.1111/j.1600-079x.1997. tb00349.x)

Pontiroli AE, Micossi P \& Foa PP 1978 Effects of serotonin, of its biosynthetic precursors and of the anti-serotonin agent Metergoline on the release of glucagon and insulin from rat pancreas. Hormone and Metabolic Research 10 200-203. (https://doi. org/10.1055/s-0028-1093434)

Pulido OM, Bencosme SA, de Bold ML \& de Bold AJ 1978 Intracellular pancreatic B cell serotonin and the dynamics of insulin release. Diabetologia 15 197-204. (https://doi.org/10.1007/bf00421239)

Richter G, Herrmann C, Goke B \& Arnold R 1989 Release of tryptophan and serotonin into the portal vein of the isolated perfused rat small intestine. Research in Experimental Medicine 189 281-287. (https://doi. org/10.1007/bf01852260)

Rosen ED \& Spiegelman BM 2006 Adipocytes as regulators of energy balance and glucose homeostasis. Nature 444 847-853. (https://doi. org/10.1038/nature05483)

Rozenblit-Susan S, Chapnik N \& Froy O 2018 Serotonin prevents differentiation into brown adipocytes and induces transdifferentiation into white adipocytes. International Journal of Obesity 42 704-710. (https://doi.org/10.1038/ijo.2017.261)

Ruddell RG, Oakley F, Hussain Z, Yeung I, Bryan-Lluka LJ, Ramm GA \& Mann DA 2006 A role for serotonin (5-HT) in hepatic stellate cell 
function and liver fibrosis. American Journal of Pathology 169 861-876. (https://doi.org/10.2353/ajpath.2006.050767)

Samuel VT \& Shulman GI 2012 Mechanisms for insulin resistance: common threads and missing links. Cell 148 852-871. (https://doi. org/10.1016/j.cell.2012.02.017)

Schoenichen C, Bode C \& Duerschmied D 2019 Role of platelet serotonin in innate immune cell recruitment. Frontiers in Bioscience 24 514-526. (https://doi.org/10.2741/4732)

Schraenen A, Lemaire K, de Faudeur G, Hendrickx N, Granvik M, Van Lommel L, Mallet J, Vodjdani G, Gilon P, Binart N, et al. 2010 Placental lactogens induce serotonin biosynthesis in a subset of mouse beta cells during pregnancy. Diabetologia 53 2589-2599. (https://doi.org/10.1007/s00125-010-1913-7)

Sidossis L \& Kajimura S 2015 Brown and beige fat in humans: thermogenic adipocytes that control energy and glucose homeostasis. Journal of Clinical Investigation 125 478-486. (https://doi.org/10.1172/ JCI78362)

Stock K \& Westermann EO 1963 Concentration of norepinephrine, serotonin, and histamine, and of amine-metabolizing enzymes in mammalian adipose tissue. Journal of Lipid Research 4 297-304.

Stunes AK, Reseland JE, Hauso O, Kidd M, Tommeras K, Waldum HL, Syversen U \& Gustafsson BI 2011 Adipocytes express a functional system for serotonin synthesis, reuptake and receptor activation. Diabetes, Obesity and Metabolism 13 551-558. (https://doi. org/10.1111/j.1463-1326.2011.01378.x)

Sumara G, Sumara O, Kim JK \& Karsenty G 2012 Gut-derived serotonin is a multifunctional determinant to fasting adaptation. Cell Metabolism 16 588-600. (https://doi.org/10.1016/j.cmet.2012.09.014)

Tecott LH, Sun LM, Akana SF, Strack AM, Lowenstein DH, Dallman MF \& Julius D 1995 Eating disorder and epilepsy in mice lacking 5-HT2c serotonin receptors. Nature 374 542-546. (https://doi org/10.1038/374542a0)

Tramer MR, Moore RA, Reynolds DJ \& McQuay HJ 1997 A quantitative systematic review of ondansetron in treatment of established postoperative nausea and vomiting. BMJ 314 1088-1092. (https://doi. org/10.1136/bmj.314.7087.1088)

Uchida-Kitajima S, Yamauchi T, Takashina Y, Okada-Iwabu M, Iwabu M, Ueki K \& Kadowaki T 2008 5-Hydroxytryptamine 2A receptor signaling cascade modulates adiponectin and plasminogen activator inhibitor 1 expression in adipose tissue. FEBS Letters 582 3037-3044. (https://doi.org/10.1016/j.febslet.2008.07.044)

Uvnas-Moberg K, Ahlenius S, Alster P \& Hillegaart V 1996 Effects of selective serotonin and dopamine agonists on plasma levels of glucose, insulin and glucagon in the rat. Neuroendocrinology 63 269-274. (https://doi.org/10.1159/000126970)

Van Assche FA, Aerts L \& De Prins F 1978 A morphological study of the endocrine pancreas in human pregnancy. British Journal of Obstetrics and Gynaecology 85 818-820. (https://doi. org/10.1111/j.1471-0528.1978.tb15835.x)

Walther DJ, Peter JU, Bashammakh S, Hortnagl H, Voits M, Fink H $\&$ Bader M 2003a Synthesis of serotonin by a second tryptophan hydroxylase isoform. Science 299 76. (https://doi.org/10.1126/ science.1078197)

Walther DJ, Peter JU, Winter S, Holtje M, Paulmann N, Grohmann M, Vowinckel J, Alamo-Bethencourt V, Wilhelm CS, Ahnert-Hilger G, et al. $2003 \mathrm{~b}$ Serotonylation of small GTPases is a signal transduction pathway that triggers platelet alpha-granule release. Cell 115 851-862. (https://doi.org/10.1016/s0092-8674(03)01014-6)

Wang Q, Wang D, Yan G, Qiao Y, Sun L, Zhu B, Wang X \& Tang C 2016 SERCA2a was serotonylated and may regulate sino-atrial node pacemaker activity. Biochemical and Biophysical Research Communications 480 492-497. (https://doi.org/10.1016/j. bbrc.2016.10.082)

Watts SW, Priestley JR \& Thompson JM 2009 Serotonylation of vascular proteins important to contraction. PLOS ONE 4 e5682. (https://doi. org/10.1371/journal.pone.0005682)

Wu J, Bostrom P, Sparks LM, Ye L, Choi JH, Giang AH, Khandekar M, Virtanen KA, Nuutila P, Schaart G, et al. 2012 Beige adipocytes are a distinct type of thermogenic fat cell in mouse and human. Cell $\mathbf{1 5 0}$ 366-376. (https://doi.org/10.1016/j.cell.2012.05.016)

Yamakawa J, Takahashi T, Itoh T, Kusaka K, Kawaura K, Wang XQ \& Kanda T 2003 A novel serotonin blocker, sarpogrelate, increases circulating adiponectin levels in diabetic patients with arteriosclerosis obliterans. Diabetes Care 26 2477-2478. (https://doi.org/10.2337/ diacare.26.8.2477)

Young SN \& Leyton M 2002 The role of serotonin in human mood and social interaction. Insight from altered tryptophan levels. Pharmacology, Biochemistry, and Behavior 71 857-865. (https://doi. org/10.1016/s0091-3057(01)00670-0)

Young RL, Lumsden AL, Martin AM, Schober G, Pezos N, Thazhath SS, Isaacs NJ, Cvijanovic N, Sun EWL, Wu T, et al. 2018 Augmented capacity for peripheral serotonin release in human obesity. International Journal of Obesity 42 1880-1889. (https://doi. org/10.1038/s41366-018-0047-8)

Zechner R, Madeo F \& Kratky D 2017 Cytosolic lipolysis and lipophagy: two sides of the same coin. Nature Reviews: Molecular Cell Biology 18 671-684. (https://doi.org/10.1038/nrm.2017.76)

Zhang X, Beaulieu JM, Sotnikova TD, Gainetdinov RR \& Caron MG 2004 Tryptophan hydroxylase-2 controls brain serotonin synthesis. Science 305 217. (https://doi.org/10.1126/science.1097540)

Zhang Q, Zhu Y, Zhou W, Gao L, Yuan L \& Han X 2013 Serotonin receptor 2C and insulin secretion. PLoS ONE 8 e54250. (https://doi. org/10.1371/journal.pone.0054250)

Zhang Y, Deng R, Yang X, Xu W, Liu Y, Li F, Zhang J, Tang H, Ji X, Bi Y, et al. 2017 Glucose potentiates beta-cell function by inducing Tph1 expression in rat islets. FASEB Journal 31 5342-5355. (https://doi. org/10.1096/fj.201700351R)

Zhang X, Wang X, Yin H, Zhang L, Feng A, Zhang QX, Lin Y, Bao B, Hernandez LL, Shi GP, et al. 2019 Functional inactivation of mast cells enhances subcutaneous adipose tissue browning in mice. Cell Reports 28 792.e4-803.e4. (https://doi.org/10.1016/j. celrep.2019.06.044)

Received in final form 20 January 2020

Accepted 24 February 2020

Accepted Manuscript published online 24 February 2020 https://joe.bioscientifica.com https://doi.org/10.1530/JOE-19-0546 (c) 2020 Society for Endocrinology Published by Bioscientifica Ltd. Printed in Great Britain 